\title{
Gender Violence in Universities in Southern Mexico
}

\author{
Ana Berónica Palacios Gámaz ${ }^{*}$, Flor Ivett Reyes Guillén², Guadalupe Palacios Gamas ${ }^{3}$, Daniel \\ Hernández Cruz ${ }^{4}$, Raúl Vázquez Martínez \\ 1, 2,3,4,5 Autonomous University of Chiapas, Mexico
}

*Corresponding Author: Ana Berónica Palacios Gámaz, Autonomous University of Chiapas, Mexico

\begin{abstract}
The purpose of this article is to deepen in the forms of expression of gender violence exercised against female undergraduate students of public universities in Southern Mexico, by actors of the university community such as teachers, classmates, university authorities and administrative personnel. The data presented here are based on quantitative research, and account for a high rate of aggression by teachers and classmates. In the university, the students are subject to gender violence in different ambits of their lives and also in institutions of higher education, which constitute a social space where a socialization is formed, traversed by acts of aggression, reproducing relations of power, domination, based on the exercise of gender violence and expresses the various forms of aggression in the social contexts in which these institutions are located.
\end{abstract}

Keywords: Gender, Violence, University, Mexico

\section{INTRODUCTION}

The information that is presented in this article is part of the results of the research called "Gender Violence in University of Southern Mexico", the data refer to undergraduate university students from public universities in Southern Mexico, specifically the University Autonomous University of Chiapas (UNACH), the Benito Juárez Autonomous University of Oaxaca (UABJO) and the Autonomous University of Guerrero (UAGRO); university students enrolled in academic units located in the capital cities of the entities of Chiapas, Oaxaca and Guerrero.

Societies today express complex and serious problems of extreme violence, according to data from the World Health Organization (WHO, 2017a) each year 1.4 million people lose their lives due to violence, equivalent to 3,800 deaths per day. Among the risk factors are alcohol, firearms, economic inequalities and gender.

Especially gender violence, specifically violence against women, in recent decades has become a complex phenomenon that has led to the exercise of serious types of violence to the extent of feminicide and suicide, which is already "a problem of global public health of epidemic proportions "according to the World Health Organization (WHO, 2013), which affects more than one third of all women worldwide: approximately one in three $(35 \%)$ of women have suffered physical violence and / or sexual partner or sexual violence by third parties at some point in their lives and up to $38 \%$ of the murders of women that occur in the world are committed by their male partner (WHO, 2017b).

Gender violence is a serious problem and affects democracy and the possibility of exercising the fundamental rights of citizens, such as the right to respect for life, liberty, physical, emotional and material security; the right to justice and to live a life free of violence.

Although in recent years there has been an advance from considering a matter of private nature to be a public issue, gender violence has not been eliminated, and according to Larena and Molina (2010) "a society that aims to guarantee conditions of quality of life, can not allow a reality of this kind to take place "(p.203).

Gender violence, and in particular violence against women, is a phenomenon product of a social process that begins in the family nucleus, where they are constituted and adjudicated referents of identity, gender-oriented roles, which structure a hierarchization of functions, of valuations between be a man or a woman, and establish rights, obligations and opportunities, generally unequal in the 
development of people. This generates the roles and stereotypes that define what it is to be a woman and a man, under conditions characterized by social inequality.

In Mexico, the General Law on Women's Access to a Life Free of Violence (LGAMVLV) (2011) classifies violence in various types: physical, patrimonial, economic, psychological and sexual. Also, these violence can occur in different forms such as: family violence, workplace violence, school violence, community violence and feminicide violence.

According to information provided by the National Survey on the Dynamics of Relationships in Households (ENDIREH) 2016 (INEGI, 2017), in Mexico 66.1\% of women aged 15 and over have suffered at least one incident of emotional and economic violence, physical, sexual or discrimination throughout their lives in at least one area and exercised by any aggressor: 49\% have suffered emotional violence, $41.3 \%$ sexual violence, $34 \%$ physical violence and $29 \%$ economic or patrimonial violence or discrimination at work.

In Mexico, there is an increase in violence against women, compared to data from 2011 to 2016, at $3.3 \%$; likewise, the increase in women physically violated by $17.3 \%$ stands out; they also increased women sexually abused by $5.9 \%$ in this same period; emotionally violated women increased $4.7 \%$ and there was a decrease of $6.3 \%$ of economically and patrimonially violated women (INEGI, 2017).

Among the five main federal entities that register the highest proportion of women victims of violence are: Mexico City, State of Mexico, Jalisco, Aguascalientes and Querétaro. Regarding the entities that treat the investigation, the state of Oaxaca registered $63.7 \%$ of women violated, the state of Guerrero $57.5 \%$ and the state of Chiapas $52.4 \%$.

With regard to women who have been violated in different areas of their lives (INEGI, 2017), we can mention that $38.7 \%$ of women (aged 15 and over) throughout their lives have suffered violence in their community; in the last 12 months, $10.3 \%$ of women have suffered family violence; $43.9 \%$ of women have suffered violence in their current or last relationship; $25.3 \%$ of women have suffered school violence throughout their lives and $26.6 \%$ of women have suffered workplace violence throughout their lives.

Of the $25.3 \%$ of women aged 15 and over who have been violated in the school environment throughout their lives as students, $16.7 \%$ have suffered physical violence, $10.9 \%$ sexual violence and $10.4 \%$ emotional violence.

The state of Oaxaca registered $28.1 \%$ of women violated in the school setting (more than the national average), Guerrero $22.8 \%$ and Chiapas registered $19.2 \%$.

In sexual violence, the main aggressors are classmates (39.9\%), followed by classmates $(20.1 \%)$, Teacher (14.4\%), unknown person in the school (11.9\%), other person in the school (5.4\%). ), Teacher (5\%), School worker (1.8\%), Principal (1.1\%), School worker (0.3\%). With regard to women who were violated in the community setting (38.7\%), ENDIREH (INEGI, 2017) indicates that $34.3 \%$ have suffered sexual violence, $14.6 \%$ emotional violence and $9.9 \%$ physical violence.

Among the five main federal entities that register the highest proportion of women who are victims of violence in their community are: Mexico City, State of Mexico, Jalisco, Aguascalientes and Queretaro. The entities that refer to this study as Oaxaca registered $26.9 \%$ of women violated in the community, Chiapas $24.8 \%$ and Guerrero $23.8 \%$.

With regard to violence in the family (do not consider the violence exerted by the husband or partner), $10.3 \%$ of women aged 15 and over who reported having suffered violence by a relative: $8.1 \%$ suffered emotional violence, $3.1 \%$ economic or patrimonial violence, $2.8 \%$ physical violence and $1.1 \%$ sexual violence. Among the main aggressors, the sibling is considered by $25.3 \%$ of the women, the father by $15.5 \%$ and the mother by $14.1 \%$. The main sexual aggressors are the uncles and the cousins.

Regarding $43.9 \%$ of women aged 15 and over who reported having suffered violence throughout their relationship with their current or last partner: $40.1 \%$ suffered emotional violence, $20.9 \%$ economic or patrimonial violence, $17.9 \%$ physical violence and $6.5 \%$ they suffered sexual violence.

Of the women who suffered physical and / or sexual violence from their current or last partner, $78.6 \%$ did not request support and did not file a complaint. Only $21.4 \%$ of the violated women are denounced and the main reason why they do not report is because it was something unimportant that did not affect them. 
The main states that registered the highest proportion of women violated by their current or last partners were: State of Mexico, Mexico City, Aguascalientes, Jalisco and Oaxaca. In the case of Oaxaca, it registered $46.1 \%$ of violated women (more than the national average), Guerrero $43.6 \%$ and Chiapas $34.9 \%$.

\section{Universities AND The Reproduction OF The CUlture OF Gender Violence}

In the case of gender violence and higher education institutions such as universities, which constitute a social space where human relationships are reproduced and also express the violent characteristics of the contexts where they are located, such as the violence of gender, generates a contradiction when considering that the general perception about universities is that they represent "the best emblem of human nature: science, progress, ethics and solidarity" (Montesinos and Carrillo, 2011).Therefore, this research aims to analyze the gender violence experienced by students from public universities in southern Mexico, specifically from the states of Guerrero, Oaxaca and Chiapas.

The assumption that guides this research is situated in a sociocultural perspective that raises the existence of cultural values that legitimize the domination of man over woman. This sexist culture has legitimized the belief in the superiority of man, which has mainly kept women in a situation of inferiority, subordination and exploitation, and justifies the exercise of violence against them.This gender violence is a social construct, characterized by aggressive behavior against people of the opposite sex, especially considering the violence exercised against women by men and expressed in the different dimensions of their social life.

The university students, notwithstanding their training situation at a professional level, are also subject to gender violence, both in the family space, in their relationship of courtship, in the place of origin and current residence, among others. This situation is also evident in the institutions of higher education where they study, a social space that plays a fundamental role in the formation and dissemination of ideologies (Castells, 2001), where human relations are reproduced and express "almost all forms of aggression that lives the society to which universities are assigned "(Montesinos and Carrillo, 2011, p.50).Among these expressions is the violence of gender and the universities are inserted in these spaces where a socialization is set through by acts of aggression, which produce and reproduce relations of power, domination, based on the exercise of gender violence. Hence, the university exercises and learns norms, behavior patterns, values that favor the internalization of sexist and patriarchal cultural patterns in society (Ruiz and Ayala, 2016).

Gender violence is a current social problem that affects mainliy women regardless of social class, age, culture or ethnicity, or academic levels and that overcomes existing stereotypes regarding the social group, causes and spaces where it occurs.

In this regard, knowledge generated in various international research (Oliver and Valls, 2004, Strauss, 2004, cited by Burgués, Oliver, Redondo and Serrano, 2006) shows that this violence is a phenomenon that is expressed in the university space, whose acceptance goes beyond cultural stereotypes, social classes and that the academic formation does not prevent being victim or perpetrator of violence; also, these studies assume that violence creates more violence, and that women violated in other stages and spaces, during their stay in the educational institution have a greater risk of being attacked in this educational space.

Larena and Molina (2010), based on the analysis developed by the social science databases ERIC, SOCIOFILE and publications of greater scientific impact ISI-Journal Citation Reports, state that the University expresses the reproduction of patterns of socialization in gender relations similar to those of the societies where they are located, coupled with the fact that it favors unequal relations derived from the permanence of strong hierarchical structures that constitute it, for which gender violence constitutes a problem present in the university space and has merited his study for years in countries whose education has been recognized for its quality.

Various investigations on gender violence in universities, according to Larena and Molina (2010), has been carried out mainly in the United States and Canada, which contribute to the understanding of the identification of gender violence, the blaming of the victims, gender socialization, models of masculinity that enhance gender violence, the characteristics of aggressors and situations of gender violence, gender violence in unequal relationships, the response of university institutions and proposals for action from the investigations. 
Higher education institutions in Mexico are not the exception as spaces where gender violence is expressed. According to Barreto (2017), gender violence in universities are frequent practices that are little recognized and investigated in Mexico. Recent studies address the experiences of university students who made public reports of the violence suffered in their institution, both of sexual abuse by teachers and dating violence, as a way to fight for the recognition of women affected by violence. gender in the university before the institutional negation (Barreto, 2017).Likewise, other researchers propose an index to measure gender violence among male and female university students (as) that allows identifying the factors that influence the reproduction of violence, the incorporation of expert opinions, as well as obtaining information on factors and perceptions of people about this phenomenon (Zamudio, Andrade, Arana and Alvarado, 2017).Another investigation reveals the different types of violence that are experienced within the university space, from the perceptions of the students, taking as a unit of analysis a university in the center of the country (Carrillo, 2014). Violence in university students is also addressed from a gender perspective to identify the correlations established between gender and homicidal and suicidal self-perception, particularly among students of a university in the Middle Region in San Luis Potosí (Rangel and García, 2012); Likewise, the different types of violence suffered by men and women in the university space (Zamudio, Ayala and Andrade, 2012) and the University as a space for reproducing gender violence (Castro and Vázquez, 2008), among others, have been studied. studies. In this sense, it is relevant to continue deepening the study of gender violence in the different contexts where higher education institutions are located in Mexico, with the aim of forming diagnoses for the design of strategies or intervention protocols.

\section{Violence in a Gender Perspective}

Gender violence is a social phenomenon that refers to the aggressions suffered by women or men due to the fact that they are, although the most frequent violence is that which is exercised against women and is not attributable to a genetic predisposition, but must be understood as a social construction, as a result of a social process that overcomes cultural stereotypes and social classes (Burgués, Oliver, Redondo and Serrano, 2006). It is fundamentally linked to the cultural dimension, since when talking about differences based on gender, it is related to the symbolic system, beliefs, values and norms attributed to the people identified in a certain gender. Generally, these representations of gender, what it is to be, act and the place that "must" occupy a man or woman in a certain society, will characterize a sexist and patriarchal culture that guides practices of discrimination, exclusion, inequality and violence in the majority of today's societies. From the perspective of Lamas (1995) "Culture marks the sexes with gender and gender marks the perception of everything else: the social, the political, the religious, the everyday" (p.4).

The creation of a sexist culture is based on inequality between men and women. According to the National Institute of Women (INMUJERES, 2016), the sexist culture refers to all those practices and attitudes that promote differentiated treatment of people based on their biological sex, from which assumed characteristics and behaviors are assumed, women and men, act daily.Sexist practices mainly affect women given the validity of cultural beliefs that consider them inferior or unequal to men by nature. The way in which these beliefs are reflected in everyday language and practices gives rise to sexism.

In the 20th century, towards the end of the 1970s, the feminist movement addressed the serious and historical situation faced by women subjected to a structured domination by a violent patriarchal culture, which in turn interacted with a capitalist economic domination (De Barbieri, 1992). Feminism became a social and political movement where women and men became aware of women, as members of the human collective, fighting against oppression patriarchal-sexist-classist domination.

The fight was in favor of nonviolence and non-discrimination, and to enforce their citizenship rights. De Barbieri (1990) notes that "through the exercise of intuition and reason at the same time, feminists launched a first hypothesis: the subordination that affects all or almost all women is a question of power, but it is not exclusively the State and in the bureaucratic apparatuses "(p.18). It would be a multiple power, located in very different social spaces.

Feminism focused on the search for a "differentiated social order within which the different dimensions are different but not separated or opposed, based on a social conception of individuality, which includes women and men as biologically differentiated beings but not as creatures. unequal "(López and Lan, 2008, p.14).The feminists carried out a real process of struggle so that women had 
the rights they deserved with the aim of improving their living conditions. According to De Dios Vallejo (2010), feminists united not only to obtain the right to vote, even though in that they emphasized their struggle, they wanted all the rights and today there is a greater awareness arising from the social reality in the midst of globalization -globalization.Currently, comments the author, located in the "Global Village" is advancing in the feminist struggle and manages the concept of gender as a social-cultural construction. In this regard, Lamas (2000) points out that within the feminist academy "the sense of gender was rephrased to allude to the cultural and thus distinguish it from the biological" (p.2).

For Scott (1990) the perspective of "gender" began to appear first among American feminists who wished to insist on the fundamental social quality of distinctions based on sex: "Gender means knowledge of sexual difference ... in the sense of understanding that cultures and societies produce about human relationships, in this case about those between men and women "(p.20). The author argues that the "gender" presents a greater link with the social sciences and thus demarcates from the politics of feminism. In the perspective of "gender" it is not represented "a necessary declaration of inequality or power, nor does it name the oppressed side" (p.6), but it refers to the unequal relations between men and women, derived from some of the parties, or also refers to sexual minorities.

Gender constitutes a core element in the constitution of social relations based on representations in line with the differences between the sexes, and it is this gender division of society that gives the sense of power in relationships. From this perspective, Delphy (1995) mentions that it establishes the existence of an aspect of sex that is constructed, different from the biological distinction. From our ancestors, this socially constructed sexual differentiation has generated, for example, the social division of labor that has fallen into discriminatory practices. It has also involved the separation of private from public life, which goes through the political order and configuration, according to Tagle (2007) of a discriminatory culture, expressed for example, in the public apparatus, political parties, unions and other social organizations, which impose resistance to women's access and participation in spaces of power.

Gender inequality is embodied in the system of values that consider superior men, therefore these values sustain inequality in access and the possibility of exercising rights, of opportunities in the social, economic, political, cultural and social spheres. Health. These inequalities imply different types of violence applied, as described by Lagarde (1996):

In his direct relationship with each man, the women of his life, his mother, his sisters, his daughters and all his relatives, as well as his girlfriends, wives and lovers, live with men under servitude, are subject to his control and extent of their violence. At the end of the second millennium, women live a maternal and symbolic inferiority: they have secondary and insignificant powers, at the same time that they are subject to the superpowers of the men who act on them, from higher positions and spaces and charged with greater powers (p. .10).

According to De Barbieri (1990), gender systems constitute the broadest object of study to understand and explain the female subordination pair-male domination. The bet is to study these systems of social action and the sense of action in relation to sexuality and reproduction. It is a category more neutral than patriarchy. As Hernández (1998) points out, gender is a concept of greater generality and understanding- since it leaves open the possibility of the existence of different forms of relationship between women and men, between the feminine and the masculine: masculine domination, feminine domination or egalitarian relations. It also leaves open the possibility of distinguishing different forms in different historical periods and as utopia, thinking about the liberation of women from other different ways of social organization.

The problem of gender refers to the phenomenon of patriarchal and sexist culture, and therefore is inserted into the cultural dimension, understood as the dimension of social existence, which is present as a factor that guides actions, practices and behaviors collective and individual (Echeverría, 2001).The naming of the realities, the concepts and categories with which we define, characterize and identify are a social, cultural construction. We refer then that being male and female, feminine and masculine, motherhood, fatherhood, heterosexuality, family, are constructs elaborated by men, and often reproduced by women, with a huge burden of oppression and inequality towards women.

These ways of representing difference and women in particular, as well as the practices in which they take shape, form patriarchal domination, which places women in subordinate social conditions and 
makes them invisible, symbolically and imaginatively; that is to say, that despite the presence of women, they are not seen, or are not identified, nor does recognition of their characteristics. Lagarde (1996) categorizes this oppression in several circumscribed dimensions in the patriarchal, class, age and racist, and considers that the sexist culture takes its state of perfection when each person is sexist with himself, when he is macho with men, and is misogynist and lesbofoba with itself.

The analysis of women and men in the context of differentiation between them is approached by the gender perspective, as a new paradigm that tries to explain the inequalities that exist between these two genders. According to Lagarde (1996) the gender perspective refers to a dimension that allows the analysis and understanding of the specificities, similarities and differences of the relationships between women and men:

analyzes the vital possibilities of women and men; the meaning of their lives, their expectations and opportunities, the complex and diverse social relations that exist between both genders, as well as the institutional and daily conflicts that must face the ways in which they do it (Lagarde, 1996, p.2).

In this way, the gender perspective and sociocultural studies are closely related, because we speak of a cultural phenomenon where systems of unequal representations are configured that guide the practices and shape relations of oppression, discrimination, inequality and violence.

In this study, gender violence is considered as an expression that refers to violence against women and according to the UN (1994), it covers various acts, although it does not limit others, such as physical, sexual and psychological violence produced and perpetrated in the family, the community, in the workplace, educational institutions and those exercised or tolerated by the State. This broad perspective includes the intimate, private and social spheres, placing violence against women as a violation of human rights and a public health problem.

In 1995, the Organization of American States declared the Inter-American Convention to Prevent, Punish and Eradicate Violence against Women, "Belem do Para Convention," which recognizes that violence against women constitutes a violation of human rights and fundamental freedoms and limits totally or partially to women the recognition, enjoyment and exercise of such rights and freedoms. Considers that violence against women is an offense against human dignity and a manifestation of historically unequal power relations between women and men; and it transcends all sectors of society regardless of their class, race or ethnic group, income level, culture, educational level, age or religion and negatively affects their own bases.

The "Convention of Belem do Para", defines as violence against women any action or conduct, based on its gender, that causes death, damage or physical, sexual or psychological suffering to women, both in the public sphere and in the private. Violence against women includes physical, sexual and psychological violence. Likewise, it recognizes that this can be done in different modalities or spaces:

a) That takes place within the family or domestic unit or in any other interpersonal relationship, whether the aggressor shares or has shared the same address as the woman, and that includes, among others, rape, abuse and sexual abuse;

b) That takes place in the community and is perpetrated by any person and that includes, among others, rape, sexual abuse, torture, trafficking in persons, forced prostitution, kidnapping and sexual harassment in the workplace, as well as in educational institutions, health facilities or any other place, and

c) That is perpetrated or tolerated by the state or its agents, wherever it occurs.

In particular in this research we focus on the violence against women that occurs in institutions of higher education, although these institutions are meant, according to Mendieta (1980), as a disciplinary organization made according to scientific purposes and cultural, to serve humanity in search of the achievement of a better world; that implement or promote training and knowledge in people, has also been a place of concentration of violence in which it has acted as a reproductive mechanism of social inequalities, race, gender and social class (Nava and López, 2010).

\section{RESEARCH METHOD}

The data presented here correspond to the quantitative research process. It was considered university students at the undergraduate level of public universities in Southern Mexico, specifically the 
Autonomous University of Chiapas (UNACH), the Benito Juárez Autonomous University of Oaxaca (UABJO) and the Autonomous University of Guerrero (UAGRO); university students enrolled in academic units located in the capital cities of the entities of Chiapas, Oaxaca and Guerrero: Tuxtla Gutiérrez, Oaxaca and Chilpancingo, respectively.

The sampling design was probabilistic, multistage and stratified. To ensure that the estimates obtained were of acceptable quality, it was necessary that the sample size defined for each parameter of interest be sufficient. The calculation of this size was related to the parameters to be estimated, the confidence level and the maximum acceptable relative error. Consequently, the size was calculated by the formula:

$$
n=\frac{N \cdot Z^{2} \cdot p \cdot(1-p)}{(N-1) \cdot e^{2}+Z^{2} \cdot p \cdot(1-p)}
$$

Where:

$n=$ Sample size.

$p=$ Proportion to estimate.

$Z=$ Number of a normal distribution associated with a desired confidence level.

$e=$ Maximum acceptable relative error.

Considering a $95 \%$ confidence $(Z=1.96)$, a maximum relative error of $5 \%$ and a proportion of 0.5 , it was determined that the overall sample size was 1,121 undergraduate university students from UNACH, UABJO and UAGRO: Chilpancingo, Guerrero of 461; for Tuxtla Gutiérrez, Chiapas for 360 and for Oaxaca, Oaxaca for 300 students.

The affixation of the sample was made within each city, between the sizes of the different universities in a proportional manner and, in the second step, within each university in each one (if another partition is going to be considered): $n_{i j}=\frac{N_{i j}}{N_{i}} n_{i}$

The survey was applied to students selected in a group manner by the academic authorities of each Degree visited and who directs the research, preferably in the last semester of the professional career, with the consent of the students; likewise, the survey was applied to randomly selected students who were outside the classroom no matter what semester they took. Which would allow the enrichment of the information obtained. The information provided by the university students in the surveys was processed with the SPSS Statistics 20 and Excel program.

\section{RESULTS AND ANALYIS OF THE INVESTIGATION}

The results of field work refer to the data obtained from the students surveyed from UNACH, UABJO and UAGRO. The bachelor's degrees that students surveyed are: Business Administration, Public Accounting, English Teaching, Mathematics, Philosophy, Librarianship, Communication, Language and Literature, Pedagogy, Computer Systems, Civil Engineering, Architecture, Human Medicine, Veterinary, Topography, Engineer Builder, Economic Sciences, Sociology, History, Education Sciences, Law, Nursing, Chemical Drugs Biologist, Dentistry, Tourism and Sustainable Development.

The students surveyed were concentrated in the following way: Chiapas 32\%, Guerrero $41 \%$ and Oaxaca $26 \%$. Of the university students surveyed, ten out of every hundred students are indigenous.

The 79\% of university students depend on their parents to survive. Likewise, 15 out of every 100 university students survive with the scholarships granted by the government and thirteen university students out of every hundred depend on their income for work. These data express a high dependence of the university students of the South of Mexico to the resources of their parents to survive and study; what Ariño (cited by Ibáñez, 2016) calls "Familism", which can lead to the reproduction of social inequalities.

Considering also, the context of high marginalization and greater population in poverty condition, the university students of public institutions face a precarious system of scholarships that do not help enough nor have a greater coverage and neither do these institutions exist a financing system for the university . The situation of university students is becoming more acute since the university curricula are not sufficiently flexible so that they can work and at the same time carry out higher level studies. 
Regarding the perception of students about their situation in the university space, it can be observed that most of them express feeling respected $(55 \%)$, supported $(40 \%)$ and a minimal proportion mentioned that they feel harassed (3\%), violated (1\%) and in a dangerous situation (1\%).

Also, according to the data obtained, most of the university students, $99 \%$, consider that the relationship with their teachers is excellent to regular, and less than $1 \%$ said that the relationship with their teachers is from bad to very bad.

However, according to information provided by the university students about different types of violence exerted against them by their professors, approximately one fifth of them (19\%) are violated by their professors. Of these, $17 \%$ are indigenous university students. According to Larena and Molina (2010), a large part of the university students tend not to recognize the gender-based violence they exert against them, tend to trust in the authority and benevolence of teachers and that those belonging to ethnic minorities are more vulnerable to these situations due to their own minority status.

Among the main types of gender-based violence that teachers exert on university students are the conditioning of qualifications (51\%), ignoring them (29\%), teasing (27\%), insults (20\%), sexual harassment $(9 \%)$, rape $(1 \%)$ and discrimination for being a woman is only indicated by $2 \%$ of the students.

About the conditioning of qualifications exercised against half of the university students, $40 \%$ of them stated that they have conditioned qualifications for money and do activities that benefit them, respectively; likewise, seven out of every hundred of them have conditioned them for sexual favors, mainly.

Regarding the frequency of the violence exerted by professors towards the university students, for most of the violated, $61 \%$, it is frequently violated; $2 \%$ has always been violated.

Among the types of support to which the university students have resorted to solve the violence suffered by the teachers, it is noteworthy that most of them, $67 \%$, have not sought any type of support and a minority of students have resorted to psychological support. (5\%) and legal support (2\%), among others.

According to the information presented above, we can point out that there is a lack of recognition of the violence experienced by the university students, combined in turn by the lack of complaints by the university students who are victims of the gender-based violence experienced. According to Valls, Oliver, Sánchez, Ruiz and Melgar (2007) this lack of identification and reporting of violence may be due to the fact that the students are afraid of not being taken seriously or that the university does not provide them with support. Also, the influence of sexist stereotypes on female university students can be considered as a determining factor, explaining that they attribute some degree of responsibility to provoking the violence exercised in them. Both these factors and some others, pay to the reproduction and perpetuation of gender violence in the university space.

Regarding the relationship with the university authorities (managers), $96 \%$ of the students consider it as excellent to be regular and $3 \%$ as bad to very bad. However, according to the data obtained from the university students about experiences of lived violence, we can point out that only $8 \%$ admit that they are violated by the university authorities.

In the types of violence exercised by the university authorities against the students, they are ignored $(70 \%)$, ridicule $(13 \%)$, qualification conditioning $(9 \%)$, insults and shouting $(6 \%)$, sexual harassment $(3 \%) . \%$ ) and $5 \%$ declare suffering discrimination for being a woman.

Regarding the frequency of violence exercised by university authorities, it is worth noting that the majority of the university students who were violated stated that they have sometimes suffered violence and two out of every 100 university students, always.

The types of support that the university students have sought or received from the university authorities, most of them (90\%), declared that they have not received any type of support and the minority ( $8 \%$ ) has received psychological support, among others.

Concerning the relations with the administrative staff, the majority of the students, $95 \%$, declared that these are excellent to regular and $4 \%$ consider them to be bad to very bad. However, according to the information provided by the university students about lived experiences of violence, we can point out that $12 \%$ of these are violated by the university administrative staff. 
About the violence exerted by the administrative staff against the university students, they are mainly: 1) the fact of denying them information $(34 \%), 2)$ hindering them $(32 \%), 3)$ shouting $(12 \%), 4)$ teasing (5\%), 5) insults (2\%) and 6) sexual harassment (2\%).

The frequency of violence exerted by administrative personnel, highlights that the majority of university students $(82 \%)$ stated that they have sometimes suffered violence; approximately eight out of every hundred university students are frequently violated and one out of every hundred university students said they are always violated.

Among the types of support to which the university students have resorted to solve the violence received by the university administrative staff, most of them (95\%) expressed that they have not received any type of support; approximately two out of every hundred university students received psychological support and one out of every hundred received medical assistance.

With regard to the characteristics of the relationship with their classmates, most of the university students $(96 \%)$, characterize it from excellent to regular and 3\% from bad to very bad. However, despite the low rate of university students who report having a bad relationship with their classmates, according to information provided by them about the types of violence suffered, approximately one fifth of university students (19\%) suffer violence from their students. classmates.

Among the types of violence exerted by classmates against university students stand out: sexual harassment $(64 \%)$, teasing (63\%), exclusion (38\%), shouting (19\%), physical violence (6\%), rape $(1 \%)$ and $6 \%$ feel discriminated against for being a woman.

The frequency of mistreatment by classmates against university students is characterized as follows: approximately two out of every 100 university students violated by classmates declared that this is always the case; for $12 \%$ it is frequent and for almost three quarters of them, it has been violated sometimes.

Most of the university students violated by their classmates, has never received any type of support and the minority declared that it has received psychological support (6\%) and legal support (2\%), among others.

Given these conditions of gender violence exercised against students by different actors of the university community, the university institution generates an adverse environment, hostile to students. In this regard, Valls et al (2007) state that the university can be constituted in a space where behaviors and institutional practices are carried out "aimed at exercising different forms of social control over women, through force, coercion, abuse or the silencing "(p.224), likewise, the institution may be hostile towards women who express resistance to accept" patriarchal structures or subordination to men in universities "(p.224).

It is important to point out that university students who have suffered domestic violence are more likely to experience situations of violence from classmates, since the data obtained indicate that $58 \%$ of the students who have suffered violence by their classmates also They have experienced violence by relatives. Likewise, approximately half of university students, $50 \%$, of those violated by teachers also experience intrafamily violence.

The data presented above shows that public universities in southern Mexico do not guarantee equality, equity and a university community free of violence. In this regard, just over a fifth of the university students declared to have knowledge of the university instances to which they can go to request support in case of suffering some type of violence.

The university students recommend that it is necessary to strengthen or create spaces and activities that generate a transformation of the sexist culture that permeates institutions of higher education, such as teaching conferences for the prevention and attention of gender violence; campaigns to raise awareness about gender respect and equity, as well as address gender-based violence, creation of a specific office for complaints of gender violence; psychological support, mentoring oriented to the prevention and attention of gender violence, strengthen the participation of women in the university, punish the violators, create and / or strengthen areas of support and guidance; disclosure of brochures, leaflets, etc.

\section{CONClusions}

The university students of the public institutions of the South of Mexico are placed in conditions of vulnerability considering the conditions of low index of human development, high marginalization 
and poverty of the context in which they are located. Also, considering the rigid characteristics of the curriculum they study, the precarious system of governmental school scholarships, the inexistence of a financing system for university students, which also do not allow the development of autonomy and do not guarantee the conclusion of your higher level studies. These conditions, together with the economic dependence of the university students in relation to their parents, mean that they do not guarantee healthy social mobility.

The present investigation expresses the little and / or null recognition of gender violence by most of the university students, whether explained by its normalization or by other factors worthy of interdisciplinary analysis. Within the consequences of this are invisibility; the low rate of university students seeking help, which may be coupled with the lack of solidarity with victims of violence and / or the tendency to blame the victim. Currently, in the university institutions, domination structures persist mainly of men towards women, which has influenced that the problem of gender violence has remained muted for a long time in the university context (Bartolo, Díaz and Díaz, 2015).

The universities are spaces where gender violence is reproduced, a hostile environment is generated mainly towards women and where "sexual harassment and misogyny are manifested in the day to day of the university, among different groups, in the curricula academics or in the debates of the classrooms. In this context there are forms of subordination and violence against women, an attempt to control them by force, domination or silence "(Larena and Molina, 2010, p.208).

The university, when expressing practices of violence against its feminine community, expresses that it has been constituted in the space to educate for competitiveness and individual success, crossed by relations of power, of subordination, discriminant and violent, based on gender inequality, social class, ethnicity, age, among others, and it is necessary to educate for the coexistence of people, for the affective, reciprocal, solidary and dignified coexistence.

The university institution of quality must consider "educating for coexistence", which implies an institution free of violence, the construction of relationships -with oneself, with other people and with the environment- based on respect, freedom, dignity, solidarity, tolerance and dialogue, within the framework of human rights (Sandoval and Garro, 2017).

Despite the progress and interest of some institutions to address and eradicate gender violence in their educational spaces, the university as a space of healthy coexistence and free of violence requires the commitment of the different actors of the university communities - teachers, students, authorities and administrative staff - for the construction of an ethos, "a way of being", based on values that are concretized in practices within the framework of human rights, which gives rise to a new way of being human.

This is how this research contributes to knowledge about the reproduction of gender violence in university institutions, convinced of the need, on the one hand, to remember the social commitment of universities and, on the other, to find ways to eradicate violence against the woman, who according to the Convention of Belem do Para, is an indispensable condition for her individual and social development and her full and equal participation in all dimensions of social life.

\section{ACKNOWLEDGMENT}

This article is the result of a research project called "Gender Violence in University Students in Southern Mexico", funded by the Secretariat of Public Education of Mexico, through the Program for Teacher Professional Development and the Autonomous University of Chiapas; It was developed in the period 2016-2017. Project identification number 23851.

\section{REFERENCES}

[1] Organización Mundial de la Salud (2017a). 10 datos sobre la prevención de la violencia. En: http://www.who.int/features/factfiles/violence/es/

[2] World Health Organization (WHO, 2013). Global and regional estimates of violence against women: prevalence ande health effects of intimate partner violence and non partner sexual violence. En: http://apps.who.int/iris/bitstream/handle/10665/85239/9789241564625_eng.pdf;jsessionid=46558D4B70D AD9C596BD8964DAC3AB7F?sequence=1

[3] Organización Mundial de la Salud (2017b). Violencia contra la mujer. Violencia de pareja y violencia sexual contra la mujer. En: http://www.who.int/mediacentre/factsheets/fs239/es/ 
[4] Larena Fernández, R. y Molina Roldán, S. (2010). Violencia de género en las universidades: investigaciones y medidas para prevenirla. Trabajo Social Global. Revista de investigaciones en intervención social, Vol.1, No. 2, diciembre, 202-219. http://tsghipatiaeditorial.com/index.php/tsg1

[5] Cámara de Diputados del H. Congreso de la Unión. México (2011). Ley General de Acceso de las Mujeres a una vida libre de violencia. En: http://www.cofemer.gob.mx/lgamvlv.pdf

[6] Instituto Nacional de Estadística y Geografía (INEGI, 2017). Encuesta Nacional sobre la Dinámica de las Relaciones en los Hogares (ENDIREH) 2016.http://internet.contenidos.inegi.org.mx/ contenidos/productos /prod_serv/contenidos/espanol/bvinegi/productos/nueva_estruc/promo/endireh2016_presentacion_ejecutiva.pdf

[7] Montesinos, R. y Carrillo, R. (2011). El crisol de la violencia en las universidades públicas. El Cotidiano, núm. 170, 49-56.

[8] Castells, M. (2001). Universities as dynamic systems of contradictory functions , en Muller, Johan et al . (eds.]), Challenges of globalisation , South African debates with Manuel Castells , Sudáfrica: Maskew Miller Longman.

[9] Ruiz Ramírez, R. y Ayala Carrillo, M. del R. (2016). Violencia de género en instituciones de educación. Revista Ra Ximhai, vol.12, núm. 1, enero-junio, 21-32.

[10] Burgués, A.; Oliver, E.; Redondo, G. y Serrano, M. A. (2006). Investigaciones mundiales sobre violencia de género en la universidad. Ponencia presentada en XI Conferencia de Sociología de la Educación. Universidad de Barcelona. En: file:///Users/anapalacios/Downloads/Dialnet-InvestigacionesMundiales Sobre Violencia De GeneroEnLa-2376722\%20(2).pdf

[11] Barreto, M. (2017). Violencia de género y denuncia pública en la universidad. Revista Mexicana de Sociología, vol. 79, núm. 2, abril-junio, 261-286.

[12] Zamudio Sánchez, F. J.; Andrade Barrera, M. A.; Arana Ovalle, R. I. y Alvarado Segura, A. A. (2017). Violencia de género sobre estudiantes universitarios(as). Convergencia Revista de Ciencias Sociales, núm. 75, septiembre-diciembre, 133-157.

[13] Carrillo Meráz, R. (2014). La violencia de género en la UAM: ¿un problema institucional o social? Revista El Cotidiano, núm. 186, julio-agosto, 45-54.

[14] Rangel Flores, Y. Y. y García Rangel, M. (2012). Violencia en estudiantes universitarios en San Luis Potosí, México: Un estudio desde la perspectiva de género. Index de Enfermería, 21(3), 141-144. https://dx.doi.org/10.4321/S1132-12962012000200007

[15] Zamudio Sánchez, F. J.; Ayala Carrillo, M. Del R. y Andrade Barrera, M. A. (2012). Violencia en el alumnado de la Universidad Autónoma Chapingo, según género. XI Congreso Nacional de InvestigaciónEducativa .Ponencia.http://www.comie.org.mx/congreso/memoriaelectronica/v11/docs/area_17/1443.pdf

[16] Castro, R. y Vázquez García, V. (2008). La Universidad como espacio de reproducción de la violencia de género. Un estudio de caso en la Universidad Autónoma de Chapingo, México. Revista Estudios Sociológicos, vol.XXVI, nú. 78, septiembre-diciembre, 587-616.

[17] Lamas, M. (1995). Perspectiva de género. Revista de Educación y cultura de la sección 47 del SNTE. En: www.latarea.com.mx/articu/articu8/lamas8.htm.

[18] INMUJERES (2016). Materiales digitales. ¡Exprésate sin sexismo!. En http://puntogenero.inmujeres .gob.mx/ madig/ sexismo/index.htm

[19] De Barbieri, T. (1992). Sobre la categoría género. Una Introducción teórico- metodológica. Revista Interamericana de Sociología, Vol. V1 ( $\left.\mathrm{N}^{\circ} 2-3\right)$, pp. 1-30.

[20] De Barbieri, T. (1990). Sobre la categoría Género. Una introducción teórico-metodológica. México: UNAM.

[21] López Pons, M. y Lan D. (2008). Democracia, género y participación política en el territorio argentino a principios del siglo XXI. Argentina: Ponta Grossa.

[22] De Dios Vallejo, D. S. (2010). El movimiento feminista en el siglo XX. En A.B. Palacios Gámaz (Edit.), Primera jornada sociológica: género, migración, movimientos sociales, identidad y educación (pp.13-42). Tuxtla Gutiérrez, Chiapas: Universidad Autónoma de Chiapas.

[23] Lamas, M. (2000). Diferencias de sexo , género y diferencia sexual . revista Cuicuilco, vol. 7, núm. 18, enero-abril, 2000, 1-24. http://www.redalyc.org/pdf/351/35101807.pdf

[24] Scott, J. W. (2008). Género e Historia. México: Fondo de Cultura Económica.

[25] Delphy, C. (1995). El concepto de género. Francia: Centro Nacional de Investigaciones Científicas Francés.

[26] Tagle, M. (2007). Participación política desde la perspectiva de género. México.

[27] Lagarde, M. (1996). Identidad de género y derechos humanos, en: L. Guzmán Stein y G. Pacheco Oreamuno (Comps.). Estudios Básicos de Derechos Humanos IV. San José de Costa Rica: Instituto Interamericano de Derechos Humanos / Comisión de la Unión Europea. pp. 85-125. 
[28] Hernández, R. (1998). Entre el etnocentrismo feminista y el esencialismo étnico. Las mujeres indígenas y sus demandas de género. México D.F. México: D.F. CIESAS/COLEM/CIAM.

[29] Echeverría, B. (2001). Definición de la cultura. México: UNAM-ITACA.

[30] Organización de las Naciones Unidas (ONU) (1994). Declaración sobre la eliminación de la violencia contra la mujer. Resolución de la Asamblea General, 20-12-1993.

[31] Organización de los Estados Americanos (1995). Convención Interamericana para prevenir, sancionar y erradicar la violencia contra la mujer "Convencion de Belem do Para". http://www.oas.org/ juridico/spanish/tratados/a-61.html

[32] Mendieta y Núñez, L. (1980). Ensayo sociológico sobre la universidad. Instituto de Investigaciones Sociales. Universidad Nacional Autónoma de México. pp.5-159.

[33] Nava Saucedo, D. C. y López Álvarez, M. G. (2010). El sexismo en la escuela primaria. Un estudio de caso en Ciudad Juárez. Educación y discriminación de género. El Cotidiano. 47-52.

[34] Ibáñez, M. J. (2016). Las desigualdades sociales se enquistan en la universidad. El Periódico.http://www.elperiodico.com/es/educacion/20160524/informe-xarxa-vives-fundacion-bofilldesigualdades-sociales-enquistan-universidad-5155170

[35] Valls, R.; Oliver, E.; Sánchez Aroca, M.; Ruiz Eugenio, L. y Melgar, P. (2007). ¿Violencia de género también en las universidades? Investigaciones al respecto. Revista de Investigación Educativa, Vol. 25, No.1, 219-231.

[36] Bartolo Nolazco, G.; Díaz González Vázquez, G. y Díaz Pérez, G. (2015). Violencia de género entre estudiantes en la Universidad Autónoma del Estado de México. URI:http://hdl.handle.net/20.500.11799/ 21892 (http://hdl.handle.net/20.500.11799/21892)

[37] Sandoval Estupiñán, L. Y. y Garro Gil, N. (2017). La Teoría Relacional: una propuesta para la comprensión y resolución de los conflictos en la institución educativa. Revista Estudios sobreEducación. Vol. 32, 135-154. DOI: 10.15581/004.32.135-154

\section{AUTHORS BIOGRAPHY}
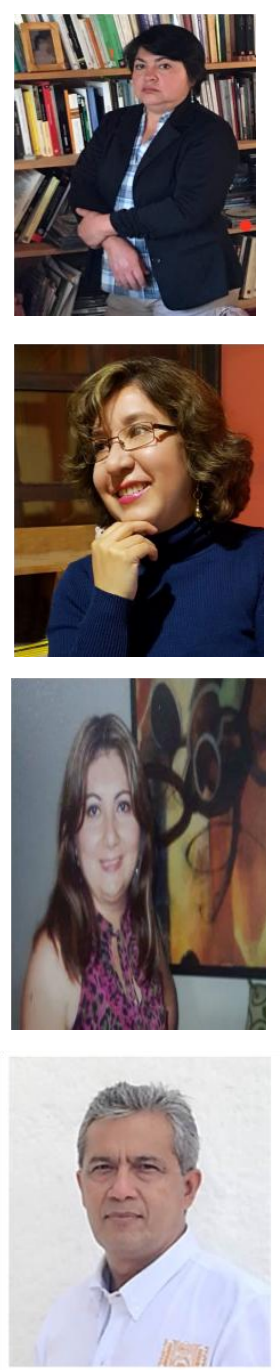

Ana Berónica Palacios Gámaz, $\mathrm{PhD}$ in Scientific-Social Studies, by the Technological Institute of Higher Studies of the West (ITESO). Teacher-Researcher of the Faculty of Social Sciences of the Autonomous University of Chiapas, Mexico. Member of the National System of Researchers. Honorary Researcher of the State System of Researchers of COCyTECH. Member of the Research Network in Public Health and Care for Development Problems, REINVESAD. Research line: culture, communication and violence.

Flor Ivett Reyes Guillén, PhD in Sciences, Natural Resources and Sustainable Development from El Colegio de la Frontera Sur. Teacher-Researcher of the Faculty of Social Sciences of the Autonomous University of Chiapas, Mexico. Member of the State System of Researchers of COCyTECH. President of the Research Network in Public Health and Care for Development Problems, REINVESAD. Research line: Cognitive analysis for the interpretation of social processes and development. Society, Sustainability and Health.

Guadalupe Palacios Gamas, Degree in Psychology from the University of Sciences and Arts of Chiapas. Head of the Gender and Inclusion Department of the Autonomous University of Chiapas. Research lines: gender violence, discrimination and exclusion.

Daniel Hernández Cruz, PhD in Educational Sciences; In addition to the specialty competencies teachers of upper middle level and a postdoctoral stay alongside Hugo Zemelman and Estela Quintar Institute Thought and Culture in America Latin. Teacher-researcher at the Faculty of Social Sciences UNACH. LGAC: policy, planning and evaluation of education; vocational training and academic careers; social representations and cognitive processes. 


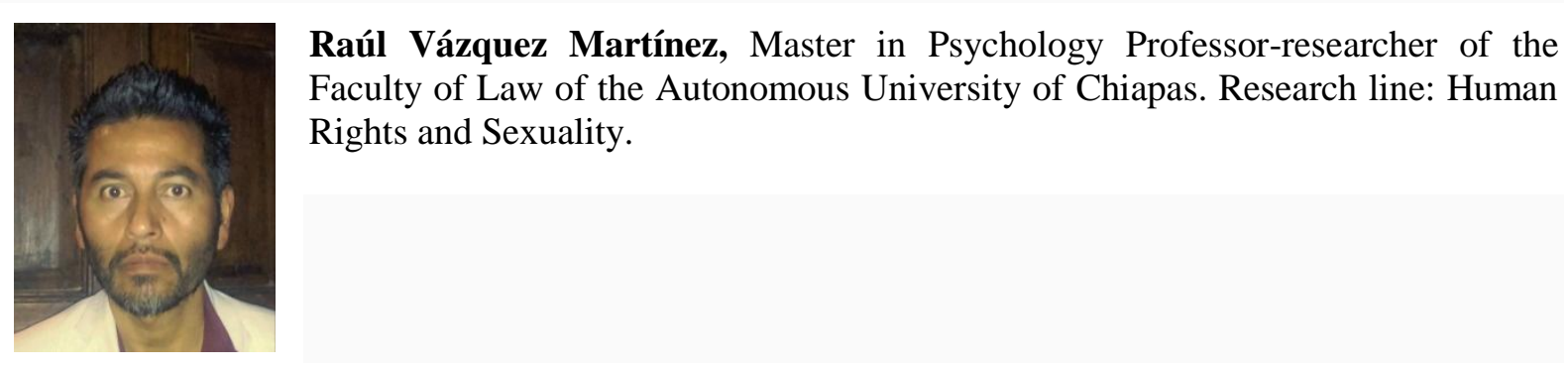

Citation: Ana Berónica Palacios Gámaz. "Gender Violence in Universities in Southern Mexico". International Journal of Humanities Social Sciences and Education (IJHSSE), vol 5, no. 4, 2018, pp. 89-101 doi: http://dx.doi.org/10.20431/2349-0381.0504011.

Copyright: (C) 2018 Authors. This is an open-access article distributed under the terms of the Creative Commons Attribution License, which permits unrestricted use, distribution, and reproduction in any medium, provided the original author and source are credited. 